\title{
SIFAT ORGANOLEPTIK TAHU SUSU DENGAN JUMLAH PEMAKAIAN KOAGULAN YANG BERBEDA
}

\author{
Dyah Ayu Pradnya Paramitha \\ Program Studi Manajemen Kuliner Politeknik Pariwisata Batam \\ Jl. Gajah Mada The Vitka City Complex, Tiban, Kota Batam, Kepri-Indonesia
}

Korespondensi dengan Penulis:

Dyah Ayu Pradnya Paramitha, Telp. : 085301446633

e-mail: dyah36@gmail.com

\begin{abstract}
Milk tofu is the result of milk production that has similar shape and color to the soybean tofu, yet its texture or elasticity is smoother than the soybean tofu. In addition, its smell is similar to the cheese smell. Data was analyzed using variance investigation and DMRT. This study is an experiment research on production of milk tofu by the use of $1 \%, 1,5 \%$, and $2 \%$ vinegar acid out of the total cow's milk. Each treatment is conducted by three times repetition. The aim of this study is to find out organoleptic characteristics that involves flavor, color, and texture through test of hedonic quality and test of hedonic. The result of hedonic test, the panelists like the flavour and texture of milk tofu which used 1,5\% of vinegar acid, and the colour of that panelists like is those that used $1 \%$ of vinegar acid.

Keywords: Tofu, Milk, Vinegar acid, Organoleptic
\end{abstract}

Air susu merupakan bahan pangan yang tersusun oleh zat-zat makanan dengan proporsi yang seimbang, mudah dicerna dan mengandung unsur zat makanan (gizi) yang dibutuhkan oleh manusia. Susu merupakan salah satu produk hewani yang cukup melimpah hasilnya di Indonesia terutama susu sapi, sebagai produk yang sangat mudah dan cepat mengalami kerusakan akibat kontaminasi bakteri dan pembusuk yang berbahaya bagi kesehatan konsumennya. Dalam penyimpanan suhu kamar pada wadah tertutup, kelayakan produk susu untuk dikonsumsi secara aman 12-18 jam (Wikipedia, 2009), penyimpanan susu segar dalam wadah terbuka pada suhu kamar tentu lebih singkat kelayakannya. Umumnya produk susu ini langsung dibuang karena telah mempunyai rasa asam dan aroma susu yang menyimpang. Tetapi produk susu yang berada pada fase ini masih dapat dimanfaatkan sebagai tahu susu. 
Tahu yang selama ini banyak dijual di pasaran merupakan produk tahu yang berbahan dasar kacang kedelai, selain dari kacang kedelai tahu juga dapat dibuat dengan menggunakan susu sapi.

Tahu adalah gumpalan protein kedelai yang diperoleh dari hasil penyaringan kedelai yang telah digiling dengan penambahan air (Sarwono dan Saragih, 2006). Penggumpalan protein dilakukan dengan cara penambahan cairan biang atau garam-garam kalsium, misalnya kalsium sulfat yang dikenal dengan batu tahu atau sioko, bahan penggumpal (koagulan) lain yang biasa digunakan dalam pembuatan tahu adalah asam asetat atau asam cuka $\left(\mathrm{CH}_{3} \mathrm{COOH}\right)$. Tahu berkualitas baik bertekstur keras sampai lunak (tergantung selera), penampakan padat dan kompak, serta mudah rapuh (hancur), rasa khas asam tahu, warna putih cerah (Sumanta, 1997).

Menurut Dewanti (2000) tahu susu merupakan hasil olahan air susu yang mempunyai bentuk dan warna mirip tahu kedelai namun teksturnya (kekenyalan) lebih halus dan baunya lebih menyerupai bau keju. Tahu susu sudah banyak dikenal di beberapa daerah misalnya di Sumatera Utara tahu susu dibuat dengan memanfaatkan bonggol nenas dengan diberi sedikit garam. Di Boyolali, tahu susu banyak digunakan sebagai bahan pencampur keju.

Pembuatan tahu susu pada prinsipnya adalah sama dengan pembuatan tahu dari kacang kedelai bahkan lebih singkat waktu pengolahannya (Astawan dalam Rokhayati, 2011). Prinsip pengolahannya yaitu menggumpalkan protein dalam susu (kasein) yang bisa dilakukan dengan menambahkan bahan yang memiliki sifat asam (Meilisa, E., dkk., 2014). Penggumpalan protein tersebut dapat dilakukan dengan cara pemanasan dan pemberian bahan penggumpal berupa enzim proteolitik ataupun bahan kimia tertentu (Dewanti, 2000).

Tahu susu diproduksi dengan memanfaatkan sifat protein susu, yaitu akan menggumpal bila bereaksi dengan asam. Bahan penggumpal yang biasa dipakai dalam membuat tahu yaitu asam cuka $\left(\mathrm{CH}_{3} \mathrm{COOH}\right)$, batu tahu $\left(\mathrm{CaSO}_{4}\right)$, dan biang tahu (whey) Sarwono dan Saragih (2006). 
Kelebihan dari asam cuka atau asam asetat yaitu mudah didapat di pasaran dan dapat langsung digunakan dalam pembuatan tahu, pembuatan tahu dengan menggunakan bahan penggumpal berupa asam lebih singkat proses pembuatannya. Penggumpalan protein oleh asam cuka atau asam asetat akan berlangsung secara cepat dan serentak diseluruh bagian cairan susu, sehingga sebagian protein yang semula tercampur dalam susu akan terperangkap di dalamnya dan akan menggumpal dengan adanya asam sehingga mengeluarkan air (whey).

Asam cuka yang beredar di pasaran merupakan asam asetat dalam kondisi pekat, asam cuka yang dipergunakan dalam pembuatan tahu susu adalah asam cuka yang mengandung $10 \%$ asam asetat alias cuka makan, dengan jumlah pemakaian yang berbeda-beda yaitu $1 \%, 1,5 \%$, dan $2 \%$ dari jumlah total susu sapi, perbedaan pada jenis dan jumlah koagulan yang digunakan menghasilkan rasa, tekstur dan rendemen tahu yang berbeda-beda (Watanabe,1997) dalam Indah (2006).
Hasil dari penelitian ini, diharapkan akan didapatkan variasi tahu susu yang baru dan disukai konsumen sehingga dapat dijadikan sebagai peluang usaha baru.

\section{METODE}

Penelitian yang dilakukan merupakan penelitian eksperimen Penelitian dilakukan terhadap tahu susu sapi dengan pemakaian jumlah asam cuka $1 \%, 1,5 \%$, dan $2 \%$, pengulangan dilkukan sebanyak tiga kali. Pengujian dilakukan terhadap sifat organoleptik yang meliputi uji mutu hedonik dan uji hedonik (kesukaan) terhadap rasa, warna, dan tekstur tahu susu dengan pemakaian jumlah asam cuka yang berbeda. Rancangan penelitian dapat dilihat pada Tabel 1 di bawah ini.

\section{Tabel 1. Rancangan Penelitian}

\begin{tabular}{cccc}
\hline Pengulangan & \multicolumn{3}{c}{ Perlakuan } \\
& & & \\
\hline P1 & P1A & P1B & P1C \\
\hline P2 & P2A & P2B & P2C \\
\hline P3 & P3A & P3B & P3C \\
\hline
\end{tabular}

Keterangan:

P1 : Pengulangan 1

P2 : Pengulangan 2

P3 : Pengulangan 3

A : Proses penambahan asam asetat $1 \%$

B : Proses penambahan asam asetat 1,5\% 
C : Proses penambahan asam asetat $2 \%$

Instrumen yang digunakan adalah format penilaian uji mutu hedonik dan uji hedonik. Uji mutu hedonik menggunakan format penilaian terhadap rasa, warna, aroma, dan tekstur. Pengisian format dilakukan dengan memberikan tanda ( $\sqrt{ }$ ) pada jawaban yang sesuai menurut panelis. Teknik yang digunakan adalah teknik scoring. Skor yang digunakan dalam penelitian berkisar antara 1-4.

Data-data penelitian diperoleh dari hasil pengisian format penilaian uji organoleptik yaitu uji mutu hedonik dan uji hedonik. Dalam penelitian ini peneliti menggunakan panelis agak terlatih. Panelis agak terlatih adalah panelis yang mengetahui sifat-sifat sensorik dari contoh yang dinilai karena mendapat penjelasan atau sekedar latihan. Panelis agak terlatih merupakan mahasiswa D3 Tata Boga Universitas Negeri Malang sebanyak 20 orang yang dipilih secara acak.

Data uji mutu hedonik yang diperoleh dianalisis dengan analisis sidik ragam untuk mengetahui perbedaan rasa, warna, aroma, dan tekstur tahu susu atau $F_{\text {hitung }}>F_{\text {tabel }}$. Apabila dari analisis sidik ragam terdapat perbedaan nyata maka analisis dilanjutkan dengan Duncan's Multiple Range Test (DMRT) untuk mengetahui besarnya perbedaan dari masing-masing perlakuan. Data uji hedonik dianalisis dengan menggunakan persentase. Perhitungan persentase untuk uji kesukaan adalah

$$
\frac{f}{n} \times 100 \%
$$

Keterangan:

$\mathrm{f}=$ Jumlah Kesukaan Panelis

$\mathrm{n}=$ Jumlah Panelis

Data yang dianalisis digolongkan dalam kriteria penafsiran yang digunakan untuk menganalisis butirbutir angket, dapat dilihat pada Tabel 2.

Tabel 2. Ketentuan Klasifikasi Persentase Uji Hedonik

\begin{tabular}{ll}
\hline Klasifikasi & Interval \\
\hline Seluruhnya & $99,1 \%-100 \%$ \\
Sebagian besar & $75^{\prime} 1 \%-99 \%$ \\
Lebih dari setengah & $50,1 \%-75 \%$ \\
Setengahnya & $49,1 \%-50 \%$ \\
Kurang dari setengah & $25,1 \%-49 \%$ \\
Sebagian kecil & $1,0 \%-25 \%$ \\
Tidak seorangpun & $0 \%$ \\
\hline
\end{tabular}




\section{HASIL DAN PEMBAHASAN}

Penelitian pendahuluan yang dilakukan bertujuan untuk menentukan rentangan dan jumlah maksimal pemakaian asam cuka sebagai koagulan dalam pembuatan tahu susu yang akan digunakan pada penelitian utama. Pada penelitian pendahuluan dilakukan pembuatan tahu susu sapi menggunakan formulasi dasar tahu kedelai dengan komposisi penggunaan asam cuka 1,48\% dari jumlah total bubur kedelai yang digunakan. Menurut Sarwono dan Saragih (2006) pemakaian asam cuka idealnya $74 \mathrm{ml}$ per $0,5 \mathrm{~kg}$ kedelai kering, atau sekitar 1, 48\% dari jumlah total bubur kedelai, oleh karena itu pada penelitian pendahuluan komposisi dimulai pada persentase asam cuka $1 \%$ karena susu sapi dengan pemakaian asam cuka tersebut dapat terbentuk gumpalan protein namun tekstur yang dihasilkan sedikit lunak/gembur. Selanjutnya untuk menentukan jumlah maksimal yaitu penggunaan asam cuka dengan persentase 3\% dari jumlah total susu sapi. Pada pemakaian asam cuka tersebut diperoleh tahu susu dengan tekstur yang terlalu kenyal atau tahu yang teksturnya mirip dengan tahu kediri dan rasa yang dihasilkan sedikit asam.

Penelitian utama dilakukan untuk mengetahui sifat organoleptik yang meliputi uji mutu hedonik dan uji hedonik terhadap rasa, warna, dan tekstur tahu susu sapi dengan pemakaian jumlah asam cuka 1\%, 1,5\%, dan 2\%. Formulasi bahan yang digunakan untuk pembuatan tahu susu sapi ditampilkan pada Tabel 4.1 sebagai berikut.

Tabel 3. Formulasi Yang Digunakan dalam Pembuatan Tahu Susu

\begin{tabular}{lccc}
\hline Bahan & $\begin{array}{c}\text { Formula- } \\
\text { si A }\end{array}$ & $\begin{array}{c}\text { Formula- } \\
\text { si B }\end{array}$ & $\begin{array}{c}\text { Formula- } \\
\text { si C }\end{array}$ \\
\hline $\begin{array}{l}\text { Susu } \\
\text { sapi }\end{array}$ & 1 liter & 1 liter & 1 liter \\
\hline $\begin{array}{l}\text { Asam } \\
\text { cuka }\end{array}$ & $10 \mathrm{ml}$ & $15 \mathrm{ml}$ & $20 \mathrm{ml}$ \\
\hline
\end{tabular}

Berdasarkan analisis data untuk uji mutu hedonik (perbedaan) dan uji hedonik (kesukaan) terhadap rasa, warna, dan tekstur tahu susu sapi diperoleh hasil sebagai berikut:

\section{Hasil Uji Mutu Hedonik Tahu}

\section{Susu Sapi}

\section{a. Rasa tahu susu sapi}

Berdasarkan hasil uji diperoleh skor rasa tahu susu sapi dengan perlakuan A adalah 2,42 yaitu cukup 
gurih, dengan perlakuan B adalah 3,43 yaitu gurih, sedangkan dari perlakuan C yaitu 1,85 yang berarti rasa tahu susu agak gurih. Pemakaian asam cuka pada pembuatan tahu susu sangat mempengaruhi rasa tahu susu. Pemakaian asam pada konsentrasi hingga 1,5\% cenderung meningkatkan rasa gurih, sedangkan pemakaian asam cuka $2 \%$ maka rasa gurih tahu susu menjadi berkurang, diduga akibat dari penambahan asam, sehingga rasa gurih tertutupi oleh rasa asam. Untuk melihat perbedaan rasa tahu susu pada masing-masing komposisi tahu susu dapat dilihat pada Tabel 4.

Tabel 4. Analisis Sidik Ragam Rasa Tahu Susu Sapi

\begin{tabular}{lllllll}
\hline $\begin{array}{l}\text { Sumber } \\
\text { Keragamam }\end{array}$ & db & JK & KT & $\mathbf{F}_{\text {hitung }}$ & \multicolumn{2}{|}{$\mathbf{F}_{\text {Tabel }}$} \\
\cline { 5 - 7 } & & & & & $\mathbf{5 \%}$ & $\mathbf{1 \%}$ \\
\hline Perlakuan & 2 & 77,23 & 38,62 & $72,87^{* *}$ & 3,00 & 4,61 \\
Kelompok & 59 & 48,9 & 0,83 & & & \\
Totat & 118 & 62,07 & 0,53 & & & \\
\hline
\end{tabular}

Keterangan:

** : Berbeda sangat nyata pada taraf signifikan $1 \%$

Hasil analisis tersebut menunjukkan bahwa pemakaian asam cuka $2 \%$ pada pembuatan tahu susu menghasilkan rasa yang kurang gurih dan rasa asam yang sedikit tajam. Tahu susu terbuat dari air susu yang telah asam. Susu mengandung asam laktat yang menyebabkan rasa asam pada susu (Ressang dan Nasution, 1982), dengan ditambahkan asam cuka sebagai bahan penggumpal menyebabkan rasa tahu menjadi asam dan rasa asam menutupi rasa gurih. Jika pemakaian asam cuka 1\% maka rasa yang dihasilkan adalah kurang gurih karena penggumpalan protein belum terbentuk dengan sempurna sehingga protein banyak yang terbuang di dalam whey.

\section{b. Warna tahu susu sapi}

Berdasarkan hasil uji diperoleh skor warna tahu susu sapi dengan perlakuan A adalah 3,57 yaitu putih susu, skor yang diperoleh tahu susu sapi dengan perlakuan B adalah 2,68 yaitu putih susu sedikit kekuningan, sedangkan skor yang diperoleh dari 
perlakuan C yaitu 2,18 yang berarti warna tahu susu putih susu sedikit kekuningan. Pemakaian asam cuka pada pembuatan tahu susu sangat mempengaruhi warna tahu susu yaitu semakin banyak asam cuka yang digunakan maka warna yang dihasilkan oleh tahu susu menjadi sedikit kekuningan karena susu mengandung pigmen karoten yang menyebabkan warna susu menjadi kekuning-kuningan. Untuk melihat perbedaan warna tahu susu pada masing-masing komposisi tahu susu dapat dilihat pada Tabel 5.

Tabel 5. Analisis Sidik Ragam Warna Tahu Susu Sapi

\begin{tabular}{lcccccc}
\hline \multicolumn{1}{c}{$\begin{array}{c}\text { Sumber } \\
\text { Keragamam }\end{array}$} & db & JK & KT & $\mathbf{F}_{\text {hitung }}$ & \multicolumn{2}{c}{$\mathbf{F}_{\text {Tabel }}$} \\
\cline { 6 - 7 } & & & & & $\mathbf{5 \%}$ & $\mathbf{1 \%}$ \\
\hline Perlakuan & 2 & 58,88 & 29,44 & $62,64^{* *}$ & 3,00 & 4,61 \\
Kelompok & 59 & 30,9 & 0,52 & & & \\
Galat & 118 & 54,02 & 0,47 & & & \\
Total & 179 & 143,8 & 30,43 & & & \\
\hline
\end{tabular}

Keterangan:

** : Berbeda sangat nyata pada taraf signifikan $1 \%$

Hasil analisis tersebut menunjukkan bahwa peningkatan pemakaian asam cuka pada pembuatan tahu susu menghasilkan warna yang sedikit kekuningan. Menurut (Muchtadi, 1997) Perubahan warna dapat disebabkan oleh asamasam organik di dalam bahan pangan yang menyebabkan warna makanan semakin gelap/kuat. Sedangkan menurut Sakidja (1989) bila protein dipanaskan dengan asam pekat maka akan dihasilkan endapan putih yang segera berubah menjadi kuning. Oleh karena itu semakin banyak jumlah atau kadar asam cuka yang ditambahkan ke dalam susu sapi maka warna tahu susu akan semakin kuning.

\section{c. Tekstur Tahu Susu}

Berdasarkan hasil uji diperoleh skor tekstur tahu susu sapi dengan perlakuan A adalah 2,15 yaitu cukup padat, skor yang diperoleh tahu susu sapi dengan perlakuan B adalah 3,68 yaitu padat, sedangkan skor yang diperoleh dari perlakuan $C$ yaitu 3,25 yang berarti tekstur tahu susu padat. Pemakaian asam cuka pada pembuatan tahu susu sangat 
mempengaruhi tekstur tahu susu, yaitu pemakaian asam cuka $2 \%$ maka akan dihasilkan tekstur tahu susu yang terlalu padat atau kenyal, sedangkan pemakain asam cuka 1\% dari jumlah total susu sapi maka tekstur tahu susu menjadi lembek karena curd tahu susu terlalu halus dan menyebabkan gumpalan protein susu sulit untuk dibentuk/dicetak. Selain itu pada pembuatan tahu susu dengan pemakaian asam cuka 1\% menyebabkan denaturasi protein belum terjadi dengan sempurna, hal ini dapat diketahui dari whey yang dihasilkan yaitu pemakaian asam cuka kurang dari 1,5\% maka whey yang akan semakin keruh. Untuk melihat perbedaan tekstur tahu susu pada masing-masing komposisi tahu susu dapat dilihat pada Tabel 6.

Tabel 6. Analisis Sidik Ragam Tekstur Tahu Susu Sapi

\begin{tabular}{lcccccc}
\hline Sumber & $\mathbf{d b}$ & JK & KT & $\mathbf{F}_{\text {hitung }}$ & \multicolumn{2}{c}{$\mathbf{F}_{\text {Tabel }}$} \\
\cline { 5 - 7 } Keragaman & & & & & $\mathbf{5 \%}$ & $\mathbf{1 \%}$ \\
\hline Perlakuan & 2 & 74,98 & 37,49 & $129,27^{\text {** }}$ & 3,00 & 4,61 \\
Kelompok & 59 & 42,19 & 0,72 & & & \\
Galat & 118 & 33,69 & 0,29 & & & \\
Total & 179 & 150,86 & 35,5 & & & \\
\hline
\end{tabular}

Keterangan:

** $\quad$ : Berbeda sangat nyata pada taraf signifikan 1

Hasil analisis tersebut menunjukkan bahwa pemakaian asam cuka $1,5 \%$ pada pembuatan tahu susu menghasilkan tekstur yang padat. Pemakaian asam cuka 2\% dari total susu sapi menyebabkan penggumpalan protein susu terjadi dengan cepat, sehingga protein whey dapat dipisahkan dengan mudah, curd yang dihasilkan juga tidak terlalu halus sehingga tekstur tahu susu menjadi kenyal dan sedikit keras.
Sedangkan dengan pemakaian cuka $1 \%$ dari total susu sapi dihasilkan tahu susu dengan tekstur yang sedikit lembek atau gembur, dan curd yang halus, karena penggumpalan protein belum terbentuk dengan sempurna.

\section{Hasil Uji Hedonik Tahu Susu}

\section{a. Kesukaan terhadap Rasa}

Panelis lebih menyukai tahu susu sapi dengan pemakaian asam cuka sebanyak 1,5\% (B) yang memiliki rasa 
gurih dari pada tahu susu dengan pemakaian asam cuka $1 \%(\mathrm{~A})$, dan $2 \%$ (C).

Rasa tahu susu sapi dengan komposisi A (pemakaian asam cuka $1 \%$ sebanyak $20 \%$ panelis menyatakan suka, 18,3\% panelis menyatakan cukup suka, 35\% panelis menyatakan agak suka, dan 26,6\% panelis menyatakan kurang suka. Rasa tahu susu sapi dengan komposisi B (pemakaian asam cuka 1,5\%) lebih dari setengah $(63,3 \%)$ panelis menyatakan suka, 23, 3\% panelis menyatakan cukup suka, 10\% panelis menyatakan agak suka, dan sebagian kecil (3,3\%) panelis menyatakan kurang suka. Sedangkan rasa tahu susu dengan komposisi C (pemakaian asam cuka $2 \%$ ) sebanyak $10 \%$ panelis menyatakan suka, $16,6 \%$ panelis menyatakan cukup suka, setengah dari panelis (50\%) menyatakan agak suka, dan $23,3 \%$ panelis menyatakan kurang suka.

\section{b. Kesukaan Terhadap Warna}

Panelis lebih menyukai tahu susu sapi dengan pemakaian asam cuka sebanyak 1\% (A) yang memiliki warna putih susu dari pada tahu susu dengan pemakaian asam cuka 1,5\% (B), dan 2\% (C).

Warna tahu susu sapi dengan komposisi A (pemakaian asam cuka 1\%) hampir seluruhnya (sebanyak 95\% panelis) menyatakan suka, 5\% panelis menyatakan cukup suka, tidak seorang pun panelis $(0 \%)$ menyatakan agak suka dan kurang suka. Warna tahu susu sapi dengan komposisi B (pemakaian asam cuka 1,5\%) lebih dari setengah $(60 \%)$ panelis menyatakan suka, 26,6\% panelis menyatakan cukup suka, $11,6 \%$ panelis menyatakan agak suka, dan sebagian kecil (1,6\%) panelis menyatakan kurang suka. Sedangkan warna tahu susu dengan komposisi C (pemakaian asam cuka $2 \%$ ) sebanyak $15 \%$ panelis menyatakan suka, 25\% panelis menyatakan cukup suka, 33,3\% panelis menyatakan agak suka, dan $26,6 \%$ panelis menyatakan kurang suka.

\section{c. Kesukaan Terhadap Tekstur}

Panelis lebih menyukai tahu susu sapi dengan pemakaian asam cuka sebanyak 1,5\% (B) yang memiliki tekstur padat dari pada tahu susu sapi dengan pemakaian asam cuka 1 \% (A), dan $2 \%(C)$. 
Tekstur tahu susu sapi dengan komposisi A (pemakaian asam cuka $1 \%$ ) sebanyak $5 \%$ panelis menyatakan suka, $18,3 \%$ panelis menyatakan cukup suka, dan sebanyak 38,3\% panelis menyatakan agak suka dan kurang suka. Tekstur tahu susu sapi dengan komposisi B (pemakaian asam cuka 1,5\%) lebih dari setengah $(73,3 \%)$ panelis menyatakan suka, 23,3\% panelis menyatakan cukup suka, sebagian kecil (3,3\%) panelis menyatakan agak suka, dan tidak seorang pun $(0 \%)$ panelis menyatakan kurang suka. Sedangkan tekstur tahu susu dengan komposisi C (pemakaian asam cuka $2 \%$ ) setengah dari panelis atau sebanyak $50 \%$ panelis menyatakan suka, $35 \%$ panelis menyatakan cukup suka, 15\% panelis menyatakan agak suka, dan tidak seorang pun $(0 \%)$ panelis menyatakan kurang suka.

\section{KESIMPULAN}

Berdasarkan hasil penelitian tahu susu sapi dengan pemakaian asam cuka yang berbeda yaitu sebanyak 1\%, $1,5 \%$ dan $2 \%$ dari jumlah total susu sapi, dari uji mutu hedonik dan uji hedonik dapat disimpulkan sebagai berikut: (1) Terdapat perbedaan rasa yang sangat nyata pada setiap perlakuan. Tahu susu sapi dengan pemakaian asam cuka $1 \%$ memiliki rasa cukup gurih atau sedikit hambar, tahu susu sapi dengan pemakaian asam cuka 1,5\% memiliki rasa yang gurih, sedangkan tahu susu sapi dengan pemakaian asam cuka $2 \%$ memiliki rasa agak gurih atau sedikit asam. (2) Terdapat perbedaan warna yang sangat nyata pada setiap perlakuan. Tahu susu sapi dengan pemakaian asam cuka $1 \%$ memiliki warna putih susu, tahu susu sapi dengan pemakaian asam cuka 1,5\% dan $2 \%$ memiliki warna putih susu sedikit kekuningan. (3) Terdapat perbedaan tekstur yang sangat nyata pada setiap perlakuan. Tahu susu sapi dengan pemakaian asam cuka 1\% memiliki tekstur kurang padat (lembek atau gembur), tahu susu sapi dengan pemakaian asam cuka 1,5\% memiliki tekstur yang padat, sedangkan tahu susu sapi dengan pemakaian asam cuka $2 \%$ memiliki tekstur padat namun agak keras (terlalu kenyal) atau mirip dengan tekstur tahu kediri. (4) Rasa tahu susu sapi yang paling disukai oleh panelis 
adalah tahu susu dengan pemakaian asam cuka sebanyak 1,5\% yaitu yang memiliki rasa gurih. (5) Warna tahu susu sapi yang paling disukai oleh panelis adalah tahu susu dengan pemakaian asam cuka sebanyak $1 \%$ yaitu yang memiliki warna putih susu. (6) Tekstur tahu susu sapi yang paling disukai oleh panelis adalah tahu susu dengan pemakaian asam cuka sebanyak 1,5\% yaitu yang memiliki tekstur padat.

\section{DAFTAR PUSTAKA}

Dewanti. 2000. Teknologi Pengolahan Hasil Ternak. Fakultas Teknologi Pertanian. Malang: Universitas Brawijaya.

Indah, Dwi. S. 2006. Pembuatan Tahu dengan Koagulan "Whey". Teknologi Hasil Pertanian: Universitas Brawijaya Malang.

Meilisa, E., dkk. 2014. Tahu Susu. [Online]. Diakses dari http://tahususuinovasipenyuluh an.blogspot.co.id/2014/05/tahususu_6910.html

Muchtadi, Tien. R. 1997. Teknologi Proses Pengolahan Pangan. Bogor: Universitas Pangan dan Gizi Institut Pertanian Bogor.

Ressang, A.A., dan A.M. Nasution. 1982. Pedoman Pelajaran Ilmu Kesehatan Susu (Milk Hygiene).
Edisi 2. Fakultas Kedokteran Hewan, IPB. Bogor.

Rokhayati, U. 2011. Pengaruh Penggunaan Asam Cuka dan Substitusi Susu Kedelai terhadap Bau Tahu Susu.Jurnal Inovasi, 8 (1), hlm.113-122.

Sakidja, M. S. 1989. Kimia Pangan. Jakarta: Depdikbud, Ditjen Dikti.

Sarwono, B dan Yan Pieter Saragih. 2006. Membuat Aneka Tahu (Cetakan 6). Jakarta: Penebar Swadaya.

Wikipedia. 2009. Tahu Susu, (online).(http:/google.co.id/Tah u Susu, diakses 11 Februari 2009). 